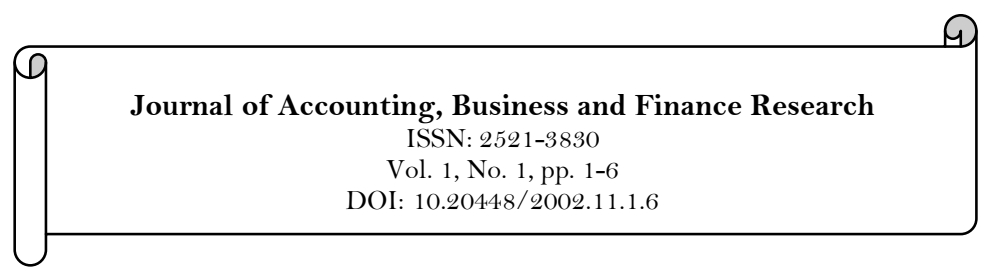

\title{
Personal Characteristics and Banking Behaviour of Customers: Further Evidence from Usmanu Danfodiyo University Sokoto-Nigeria
}

\author{
Haruna Mohammed Aliero ${ }^{1}$ \\ Ibrahim Hussaini Aliero ${ }^{2}$ \\ Sulaiman Zakariyya' $\mathbf{u}^{3}$
}

${ }^{1}$ Professor, Department of Economics Usmanu Danfodiyo University Sokoto-Nigeria.

${ }^{2}$ Senior Lecturer, Department of Economics Usmanu Danfodiyo University Sokoto-Nigeria.

${ }^{3} \mathrm{M}$. Sc. Student, Department of Economics Usamnu Danfodiyo University Sokoto-Nigeria.

\begin{abstract}
"This study examines the extent to which customers' personal characteristics have influence on the banking bahaviour of customers. The study uses primary data which was collected from the Usmanu Danfodiyo University Sokoto. A sample of 383 respondents was used cutting across staff, students and petty business operators within the community. The study uses Logistic regression model to analyse the data. The results of the study indicated that age, marital status, and occupation have negative influence on the banking bahviour of customers while, educational qualification and monthly income have positive influence. The study therefore recommends that those factors with positive influence should be closely watched whenever banks are looking for customers in the community and other communities with similar features.”
\end{abstract}

\author{
Keywords: \\ Bank \\ Customer \\ Bank customer \\ Banking behaviour \\ Nigeria. \\ Licensed: \\ This work is licensed under a \\ Creative Commons Attribution \\ 4.0 License. \\ Publisher: \\ Scientific Publishing Institute
}

\section{Introduction}

Different people visit banks for different reasons. While some people go to a bank to cash their personal cheque or cheque issued in their favour by third parties, others go to deposit cash or cheques into their accounts. There are also people who visit banks occasionally to purchase drafts or travellers cheque. Therefore, it is not easy to come by any single accepted definition of a bank customer and by implication there cannot be any statutory definition of a bank customer. However, scholars have always suggested resorting to the decisions of the courts in order to discover the principles that determine whether or not a person is a customer. In the United States, Sect. 4-104 (1) (e) (1957) of the Uniform Commercial Code defines bank customer as "any person having an account with a bank or for whom a bank has agreed to collect items and includes a bank carrying an account with another bank". In Great Western Railway Company v. London and County Banking Co. Ltd (1901), it was held that to constitute a person a 'customer' there must be some type of account either a deposit or current account or some similar relation and that a person who had been cashing cheque from the defendant bank over several years was not a customer of the bank by merely cashing cheque. There must be much more than mere cashing of a cheque to make one a customer. In Ladbroke \& Company v. Todd (1914) a crossed cheque issued by Ladbroke \& Co. was stolen and through false representation, the banker Todd to open a current account for the thief with the amount of the cheque. The banker (Todd) later claimed the protection of S.82 of the UK Bills of Exchange Act 1882 (now S.4 of the checks Act 1957) which is similar to S.2 of the Nigerian Bills of Exchange Act 1964, on the grounds that it had collected the cheque in a good faith and without negligence on behalf of the customer and the contention was upheld (Adekanye, 1986). The essential condition (which has been adopted in Nigeria) is that a person must have opened an account with the bank and have at least one transaction on the account before he can be classified as customer. In 1920 the Privy Council reaffirmed this position in the case of Commissioner of Taxation v. English, Scottish and Australian Bank. Customers are presumed to be one of the most important stakeholders in any business organization because without them, business organizations are not likely to succeed. Hence, marketers emphasize on research in the area of consumer behavior and particularly behavioral intention. Knowledge of category of consumers and their behavior will go a long way in ensuring effective marketing policies towards the interest of customers which will eventually facilitates positive customer attitude towards the organizations. Exploring such information will assist banks to recognize the appropriate marketing strategies 
needed to attract new customers and retain existing ones (Kaynak \& Kucukemiroglu, 1992). The objective of this paper therefore is to analyse the influence of the bank customers' personal characteristics on thier choice of a bank. To achieve this objective the paper is presented in five parts. Part one is this introduction, part tow is the literature review, part three presents the methodology used in the analysis, part four is the analysis of the data collected while the fifth part contains the summary, conclusion and recommendation.

\section{Literature Review}

Literature on banking is actually abundant however; the concern in this work is strictly on the bank customers' personal characteristics and its influence on the customers' choice of a bank. In a work conducted by Vasanthakumari and Rani (2011) they investigated the banking behaviour of retail banking customers in Chennai. The authors conducted a comprehensive profile analysis, a number of ANOVA, t test and factor analysis used for finding the banking behaviours of retail banking customers. First, most of the customers fall in the age group of 18-30 years and they are highly educated and have durable relationship with the banks. Age and income of the respondents have a significant role in the customer preference for selecting a bank and the gender does not influence the customer preferences of banks. Machauer and Sebastian (2001) studied the use of segmentation by demographic factors in bank marketing and found that the correlation of such factors with the needs of customers is often weak. Using cluster analysis the study formed segments based on combinations of customer ratings for different attitudinal dimensions and benefits of bank service.

On the other hand, Kaynak, Kucukemiroglu, and Odabasi (1991) reported differences in bank selection criteria based on gender, age and educational background of bank customer in Turkey. This study reported that male customer put more importance on reputation of the bank, business hours, parking facilities, availability of wide-range of services, and fast and efficient services than the female customers. The convenience (especially bank location) played important role for customer under age 40. According to educational segmentation, customers with more than primary education considered empathy, fast and efficient services, location of the banks more important than the uneducated group. Selection factors of which both single and multiple bank users had variation were attractiveness, branch location, ATM service, financial benefits and secure feeling. Multiple-bankers appear to place significantly more importance to all these factors. Female customers engage in multiple banking significantly more than their male counterparts. In Bangladesh, Rashid and Mohammed (2009) conduct a study on customer demographic affecting bank selection criteria, preference, and market segmentation. The result of the study shows that mostly, un-Islamic factors such as Corporal Efficiency, Core-Banking services, Confidence, etc. were given higher weights by majority of the respondents

In a somewhat similar study, Omar (2007) investigated the relative importance attached to retail banks' choice criteria used by male and female customers. The results show that both male and female customers value their time highly and expect their banking transactions to be completed as quickly as possible. In general, there were only few differences between male and female customers. Males seemed to be more confident in managing money and taking greater risks. Female customers on the other hand are not economical when it comes to spending. They seem to look for immediate gratification through spending, more security-oriented in money handling, and are fearful of negotiating large purchases. There are likely to be increasing numbers of women who have large amounts of disposable income resulting from their move into professional occupations once defined as exclusively male. In another study Mokhlis (2009) studied gender differences and the relative importance of choice criteria in respect of selecting a retail bank. The study employed quantitative methodology to analyse the 368 responses of the Malaysia's undergraduates, he found that there are some differences in the choice factors employed by male and female customers in selecting a bank for patronage. Factors of which both male and female had variation are attractiveness, marketing promotion, ATM service, proximity, people influences and financial benefits.

In their study Rashid and Mohammed (2009) examined the impact of demographic disparities on the bank selection criteria used by different customers of domestic Islamic banks in Bangladesh. The authors run a regression analysis after controlling for four demographic groupings which include Gender, Marital Status, Age and Educational Qualification. The beta scores were taken for identifying the influential factors chosen by the customers of Islamic Banks. Mostly, non-Islamic factors such as Corporal Efficiency, Core-Banking services, Confidence, etc. were given higher weights by majority of the respondents. Khan, Hassan, and Shahid (2008) studied the banking behaviour of Islamic bank customers in Bangladesh. By collecting data from a sample of 100 customers of Islamic banks, they conducted a comprehensive profile analysis, a number of chisquare tests, and t tests and found a number of key findings as to the behaviour of Islamic bank customers in Bangladesh. First, most of the customers of Islamic banks fall in the age category of 25-35 years. Islamic bank customers are highly educated and have durable relationships with the banks. Second, high customer awareness and usage exist for various deposit mobilization instruments but there is not high awareness and usage of any individual financing facilities of Islamic banks. Third, income category and education have a significant role in customers' usage of various Islamic bank products/services. Fourth, customers seem to be satisfied with a number of products/services of Islamic banks. Fifth, among the service delivery elements, 'employees' deserve an immediate attention for improving customer satisfaction. Finally, 'religious principles' 
is the key bank selection criterion of the Islamic bank customers, while customers' demography plays some role in determining which selection criteria matter more than others do.

Frangos, Fragkos, Sotiropolous, Manolopoulos, and Valvi (2012) also conducted a study to identify the factors that influence Greek customers' decision to take out a loan from commercial banks. They randomly selected a sample of 277 Greek citizens in order to test the hypotheses, using a questionnaire with selfdetermined scales. A number of variables (demographics, service quality and satisfaction) have been examined as potential factors influencing customers' decision to take out a loan. After using Logistic regression, the results show that personal marital status, customer service, shop design and interest rates are the most significant predictors of taking loans. Similarly, Ahmad, Saif, and Safwan (2010) examined the perception of bank customers regarding service quality of the Islamic banks in comparism with conventional banks in Pakistan. Data were collected from 720 bank customers by using stratified random sampling. It was found that the perception of customers of Islamic banks regarding service quality is higher than the perception of customers of conventional banks. The results indicate that there is significant difference in perception of service quality among customers of Islamic banks on the basis of gender but there is no significant difference in service quality perception of male and female customers of conventional banks. Safakli (2007) also conclude that that the chief factors determining customers' bank selection are: Service Quality and Efficiency, Bank Image, Convenient Location, Parking facilities, financial factors and Affected opinion. The findings also show that it may be necessary to deal with different demographic characteristics of respondents as distinctive $\backslash$ segments with different priorities in their bank selection process

In the same vein, Mokhlis, Mat, and Salleh (2010) empirically investigates variation in bank choice criteria between three distinct cultural groups in Malaysia, namely Malays, Chinese and Indians. The authors predicted that, due to differences in values and lifestyles of the three ethnic groups, cultural differences would be observed in the level of important members of each group attached to specific bank choice criteria. A quantitative methodology, using responses given by 482 Malaysia's undergraduates, is employed in the analysis. The results of this comparative analysis indicate that there is a difference in bank choice criteria based on ethnic backgrounds. Cicic, Brkic, and Agic (2004) investigated the attitude of 300 students aged 1924 years of the University of Sarajevo in Bosnia and Herzegovina to examine the customers' bank selection criteria. Their findings disclose that the main factors determining students' bank selection are: reception at the bank, friendliness of bank personnel, low service charges, ease of opening a current account, and confidence in bank management.

\title{
3. Methodology
}

This study is an empirical work, which uses primary data collected from Usmanu Danfodiyo University Sokoto Nigeria. Sokoto is the headquarters of Sokoto state and it is located in the North-western part of Nigeria. It is predominantly dominated by Hausa-Fulani with some other tribes all of whom could fluently relate in the Hausa language. The data used for the study was primary data. Non-probability (convenient) sampling method was adopted in collecting the sample; this is because of the absence of any usable sampling frame. The sample size for the study was 383 respondents comprising of University staff, students and business operators on campus. The choice of the sample size was based on $5 \%$ merging of error and $95 \%$ confidence interval. The data were collected through the administration of structured questionnaire, however, out of the 383 questionnaires administered only 362 questionnaires were returned, out of which twelve were wrongly filled leaving us with 350 representing $91 \%$. The data collected was sorted and coded before being analyzed. In analyzing the data collected Logistic regression was used as stated below:$$
S B S=\beta_{0}+\beta_{1 A G E}+\beta_{2 E D Q}+\beta_{3 M I M}+\beta_{4 M R S}+\beta_{5 O C P}+\mu_{\ldots \ldots . . e q .(2)}
$$ \\ Where: \\ SBS $=$ Selection of Banking Services \\ $\mathrm{AGE}=$ Age of the Respondent \\ EDQ = Educational Qualification of the Respondent \\ MIM $=$ Monthly Income of the Respondent \\ MRS = Marital Status of the Respondent \\ OCP $=$ Occupation of the Respondent \\ $\beta_{0}=$ Constant Parameter \\ $\beta_{s}=$ Coefficient of the independent variables \\ $\mu=$ Error term, which takes care of other factors that might influence selection of banking
} services but not captured in the model.

Variable Measurement

The value of any particular variable depends on the condition under which it is taken. Variables are the condition or characteristics that the experiment manipulate, control or observes.

The variables captured in the model specified for this study are measured as follows: 
Dependent Variable

Selection of Banking Services (SBS) is measured in form of binary numbers or dummy variables where

$1=$ Selection

$0=$ Non Selection

Independent Variables of the Second Model

Where:

$\beta_{1}=$ Age

Where: $1=18-30,2=31-40,3=41-50,4=51-60,5=60$

$\beta_{3}=$ Educational Qualification

Where: $1=$ undergraduate, $2=$ Postgraduate $3=$ Others

$\beta_{3}=$ Monthly Income:

Where: $1=<20,000,2=21,000-40,000,3=41,000-60,000,4=61,000-80,000,5=81,000-100,000$ and $6=$ above 100,000

$\beta_{4}=$ Marital Status

Where:

$1=$ Single

$2=$ Married

$3=$ Divorce

$4=$ Widow

$\beta_{5}=$ Occupation:

Where:

1 = Student,

$2=$ Businessmen/women

3 = Employee

\section{Result and Discussion}

This section presents the analysis of the data collected. The data is presented in two different tables each containing a different segment of the analysis. We begin with the demographic profile of the respondents in the table below:

Table-1. Demographic profile of the respondents.

\begin{tabular}{|c|c|c|}
\hline Particulars & Frequency & Percent \\
\hline & Age of the respondent & \\
\hline $17-30$ & 292 & 83.7 \\
\hline $31-40$ & 42 & 12.0 \\
\hline $41-50$ & 11 & 3.2 \\
\hline $51-60$ & 2 & 0.6 \\
\hline \multirow[t]{2}{*}{ Above 60} & 2 & 0.6 \\
\hline & Sex & \\
\hline Male & 215 & 61.4 \\
\hline \multirow[t]{2}{*}{ Female } & 135 & 38.6 \\
\hline & Educational Qualification & \\
\hline Undergraduate & 260 & 74.3 \\
\hline Postgraduate & 78 & 22.3 \\
\hline \multirow[t]{2}{*}{ Others } & 10 & 2.9 \\
\hline & Monthly Income & \\
\hline$<20,000$ & 93 & 52.2 \\
\hline $21,000-40,000$ & 32 & 18.0 \\
\hline $41,000-60,000$ & 15 & 8.4 \\
\hline $61,000-80,000$ & 5 & 2.8 \\
\hline $81,000-100,000$ & 15 & 8.4 \\
\hline \multirow[t]{2}{*}{$>100,000$} & 18 & 10.1 \\
\hline & Marital Status & \\
\hline Single & 247 & 70.6 \\
\hline Married & 100 & 28.6 \\
\hline Divorce & 2 & 0.6 \\
\hline \multirow[t]{2}{*}{ Widow } & 1 & 0.3 \\
\hline & Occupation & \\
\hline Student & 263 & 76.5 \\
\hline Businessman/women & 10 & 2.9 \\
\hline Employee & 71 & 20.6 \\
\hline
\end{tabular}


Personal characteristics of the sampled population is outlined in Table 1 and the result indicated that out of three hundred and fifty (350) respondents two hundred and ninety two (292) equivalent to $83.7 \%$ fall into age bracket of 17-30, forty-two of them representing $12 \%$ are in the age group of 31-40 while 51-60 and those above 60 years recorded the least percentage of $0.6 \%$ respectively. It can therefore be inferred that majority of the respondents in the study area are youth. With respect to respondents' gender, two hundred and fifteen (215) or $61.4 \%$ are males while the female constitute one hundred and thirty five (135) representing $38.6 \%$. Knowing fully-well, the study area is an academic environment it is expected that higher percentage of the respondents would be youths. In considering educational qualification, the result shows that two hundred and sixty (260) representing $74.3 \%$ are undergraduates while postgraduate constituted $22.3 \%$ representing seventy eight (78) respondents. The remaining $2.9 \%$ have "other" qualifications that are not specified. In terms of monthly income, more than half of the respondents (52.2\%) earn less than 20,000 Naira monthly. Thirty two people (32) corresponding to $18 \%$ earned monthly income ranging 21,000-40,000Naira, while $10.1 \%$ of the respondents earned more than one hundred thousand (100,000) naira monthly, the remaining $8.4 \%$, and $2.8 \%$ constitutes the number of respondents that earned monthly income ranging from 41,000-60,000; 61,00080,000 and 81,000-100,000 respectively. Since the greater percentage of the respondents are undergraduate, it is therefore not surprising to realise that majority earn less than 20,000 naira monthly. This is because they mostly depend on subvention or monthly allowance from their parents. In terms of marital status, $70.6 \%$ of the respondents are single, $28.6 \%$ are married while $0.6 \%$ are divorcees and $0.3 \%$ are widows. With respect to the respondent's occupation, $76.5 \%$ are students while $20.1 \%$ are employees, and the remaining $2.9 \%$ are businessmen/women operating in the University. The higher percentage of the respondents being single is probably because most of the respondents are students not working class.

Table-2. Regression Results Relating Personal Characteristics to Customres' Bank Selection Decision.

\begin{tabular}{lc}
\hline Age & $-0.945(4.723)^{*}$ \\
\hline Educational qualification & $1.663(3.048)^{*}$ \\
\hline Monthly income of the respondents & $1.921(5.200)^{*}$ \\
\hline Marital status & $-4.626(5.550)^{*}$ \\
\hline Occupation & $-0.945(1.617)$ \\
\hline NagelkerkeR ${ }^{2}$ & 0.644 \\
\hline Chi $^{2}$ value & $24.277^{* * * *}$ \\
\hline **** Significant at $1 \%, * *$ significant at $5 \%, *$ significant at $10 \%$. & \\
Source: Computed by the Author from Field Survey June, 2014.
\end{tabular}

From Table 2 above, age has a negative influence on customer choice of a bank although the coefficient is only statistically significant at $10 \%$ level. This indicates that age has nothing to do with bank selection decision. On the other hand, Coefficient of educational qualification 1.663(3.048) is positive and significant but at $10 \%$ level also. This shows that level of education influence customers' bank selection of a bank. This implies that the more customers are educated the more they become very sensitive with regard to their choice of bank. Furthermore, income also influence customers' choice of a bank, the coefficient of income 1.921(5.200) is positive and significant at $10 \%$. This indicates that level of income of customers played a significant role in banking selection. However, marital status does not influence customers' choice of a bank since the coefficient is $-4.626(5.550)$ which is statistically significant.

Also, from the Table 2 above the variation of the dependent variable is approximately $64 \%$ jointly explained by the independent variable given by nagelkerke $R^{2}$ while the remaining $36 \%$ is explained by other variables not captured in the model.

\section{Conclusion and Recommendation}

This study examines the influence of personal characteristics of individuals on their bank selection behaviour using Usmanu Danfodiyo University Sokoto-Nigeria as a case study. The findings of this study revealed that, personal characteristics such as age, marital status, and occupation negatively influence customer choice of a bank. On the other hand, educational qualification and monthly income exert positive influence on customer choice of a bank which implying that, level of education as well as income influence customers' decision in selecting a bank. This therefore means that banks should take these factors into consideration when they are planning any package to attract customers, particularly in this community and other communities with similar features.

\section{References}

Adekanye, F. (1986). The element of banking in Nigeria (3rd ed.). UK: Graham Burn.

Ahmad, A., Saif, I., \& Safwan, N. (2010). An empirical investigation of Islamic banking in Pakistan based on perception of service quality. African Journal of Business Management, 4(6), 1185-1193.

Cicic, M., Brkic, N., \& Agic, E. (2004). Bank selection criteria employed by students in a South-eastern European country: An empirical analysis of potential market segments' preferences. Paper presented at the In Australia and New Zealand Marketing Academic Conference 2004. 
Frangos, C. C., Fragkos, K. C., Sotiropolous, L., Manolopoulos, G., \& Valvi, A. C. (2012). Factors affecting customers' decision for taking out bank loans: A case of Greek customer. Journal of Marketing Research and Case Studies, 2012, 16.

Kaynak, E., \& Kucukemiroglu, O. (1992). Bank and product selection: Hong Kong. International Journal of Bank Marketing; $10(1), 3-16$.

Kaynak, E., Kucukemiroglu, O., \& Odabasi, Y. (1991). Commercial bank selection in Turkey. International Journal of Bank Marketing, 9(4), $30-39$.

Khan, M. S. N., Hassan, M. K., \& Shahid, A. I. (2008). Banking behavior of Islamic bank customers in Bangladesh. Journal of Islamic Economics, Banking and Finance, 161-194.

Machauer, A., \& Sebastian, M. (2001). Segmentation of bank customers by expected benefits and attitudes. International Journal of Bank Marketing, 19(1), 6 - 18.

Mokhlis, S. (2009). Determinants of choice criteria in Malaysia's retail banking: an analysis of gender-based choice decisions. European Journal of Economics, Finance and Administrative Sciences, 1(2), 1450-1467.

Mokhlis, S., Mat, N. H. N., \& Salleh, H. S. (2010). Ethnicity and choice criteria in retail banking: A Malaysian perspective. International Journal of Business and Management, 5(6), 98-105.

Omar, O. E. (2007). Gender-based retail bank choice decisions in Nigeria. Journal of Retail Marketing Management Research, $1(1), 20-31$

Rashid, M., \& Mohammed, K. H. (2009). Customer demographics affecting bank selection criteria, preference, and market segmentation: study on domestic islamic banks in Bangladesh. International Journal of Business Management, 4(6).

Safakli, O. V. (2007). A research on the basic motivational factors in consumer bank selection: Evidence from Northern Cyprus. Banks and Bank Systems, 2(4), 93-100.

Vasanthakumari, M. S. H., \& Rani, S. S. (2011). Factors influencing selection of retail banking -a study on customer preferences. Journal of Empirical Research in Management, 1. 